\title{
From Aggression to Acceptance: The Shifting of Quebecois Nationalist Attitudes in Relation to Indigenous Nationalism in Canada
}

\author{
By Andrew McWhinney
}

\begin{abstract}
This essay examines the shifting relationship between Quebecois and Indigenous nationalism, tracing a historical path from post-Quiet Revolution Quebec to the signing of the "La Paix des Braves" document in 2002. Nationalist attitudes in Quebec were initially hostile towards their Indigenous counterparts, due to the Indigenous push of a three-nation conception of Canada which undermined the Quebecois dualist English-French founding narrative upon which Quebecois nationalist claims rested. This essay argues that Quebecois nationalist attitudes have grown more accepting over time in response to popularization of the three-nation conception of Canada, and that Quebec's unique hybrid position as a decolonizing nation and a settler-colonial nation has allowed it to do so through recognition of Indigenous peoples as co-colonized by the Canadian state. This shift from aggression to tolerance is shown through examinations of historical moments such as the James Bay Agreement, the Meech Lake and Charlottetown Accords, and the Oka Crisis.
\end{abstract}

\section{Introduction}

During the Quiet Revolution, Quebec nationalism shifted focus from survival of a French-Canadian culture to a distinctly Quebecois ethnic identity. Quebec nationalists began to aspire for further recognition as a distinct society in Canada, bringing them into direct conflict with not just the Canadian government, but with another ethnic nation also striving to legitimize their nationalist claims: Indigenous peoples. After the introduction and rejection of the White Paper in 1969 , Indigenous nationalism began to rise in prominence in Canadian politics in conjunction with Quebecois nationalism. In this paper, I shall address the precise nature of Quebecois nationalism in post-Quiet Revolution Quebec, why and how it conflicted with rising Indigenous nationalism during this period, and how the Quebecois attitude towards Indigenous nationalism has shifted due to these conflicts. I will argue that Quebecois nationalists saw Indigenous nationalists' "three-nation" conceptualization of Canada as a threat to their own political claims, which relied upon a dualist narrative of Canada; this in turn influenced Quebec policy towards Indigenous claims, shifting it from hostile to begrudgingly accepting as the prevalence of the three-nation conceptualization of Canada became more universally accepted. Case studies such as the 1975 James Bay Agreement, the Meech Lake and Charlottetown Accords, and the Oka Crisis will be explored to trace this historical shift towards tolerance, culminating in the "La Paix des Braves" document that demonstrated symbolic recognition of Indigenous nationhood by Quebec.

\section{Formulations of Quebecois and Indigenous Identity Within Canada}

After the Quiet Revolution, the perception of Indigenous peoples by Quebecois nationalists was dominated by three figurations, as reflected in the works of Quebecois essayists: one of non-existence, one 
of threat to Quebec sovereignty, and one of co-colonization. The denial and dismissal of Indigenous peoples from the Quebec political identity came from a desire "to inscribe Quebec identity in a framework of duality with English Canada” (Hobbs 2008, 309). Such an inscription was desirable as it would allow for Quebec nationalists to portray themselves as a decolonizing nation pitted against an oppressive English Canada. Besides demanding asymmetrical federalism in order to obtain greater control over cultural and economic legislation, Quebecois society also mirrored pan-Canadian civil society organizations in order to distinguish differences in policy; for example, the Canadian Council on Social Development is paralleled by a Conseil Québécois de Développement Social (McRoberts 200I, 689). This portrayal was an ironic one, however, because it ignored the fact that Quebec itself was attempting "to assert its legitimate presence on territory formerly occupied by the Native peoples of Quebec" (Hobbs 2008, 3IO). Some Quebecois believed that Quebec and Indigenous peoples were in "a competition for legitimacy in claims for sovereignty" (Hobbs 2008, 3IO), therefore making Indigenous peoples a threat to the economic and political development of a decolonizing Quebec. Such attitudes manifested themselves vividly in the public domain like they did in the treatment of Indigenous groups during the negotiations of the James Bay Agreement, as well as during the Oka Crisis.

Besides these two primarily antagonistic figurations, the figuration of Indigenous peoples as cocolonized is unique. In this view, Quebecois saw "[Indigenous peoples] as sharing the same fate... [of being] disadvantaged and exploited... under the [same] federal structure" (Hobbs 2008, 3I5), comparing their nationalist struggles to those of Indigenous peoples. This, in contrary to other figurations, puts both groups on equal footing. The other side to this figuration saw the Indigenous struggle as more of a "premonitory tale of what would befall Quebec unless action were taken to reverse the trend towards assimilation" (Hobbs 2008, 3I5). Some Quebecois also identified similarly with other minority groups such as Black Canadians and African Americans, comparing the hard work of their poor to "Black slaves," as well as claiming "racial discrimination at the hands of English Canadians, while being culturally oppressed and economically exploited by both English Canada and the US" (Austin 2OIO, 24). This contrasting is further complicated by the fact that Quebec engaged in the "colonisation [sic] of Indigenous peoples and the practice of slavery" during the New France period (Austin 2OIO, 25). The contrasting of these figurations reflects Quebec's unique position as a hybrid of settler colonial and decolonial elements. I believe that this unique collection of cultural portrayals allowed for Quebec nationalism to take a more accommodating and cooperative approach to relations with Indigenous peoples in Canada as the national narrative shifted; without the presence of a certain degree of identification, albeit one that was seriously skewed and racialized, it would be unlikely that relations between the two nations would be amicable.

The ability for Indigenous peoples to name themselves as a unique nation within Canada has allowed them to "undermine the system of recognition upon which the Quebecois and 'English-Canadian' identities have long depended" and thus "challenge the privileged access to the institutions of federalism enjoyed by existing groups, including provinces" (Jenson I993, 350). The main feature of their nationalist goals that undermines Quebecois recognition is the belief in a three-nation conception of Canada that "makes it possible to recognize, simultaneously, the distinctiveness of Quebec within federal institutions [and] the Aboriginals peoples' inherent right to self-government" (Jenson I993, 349). While such a view is challenging to the established master narratives of Canada and Quebec, as it requires a re-examination of history and embedded values in the Canadian polity, its ability to constantly provide mutual recognition of these three nations is not unwholly unattractive; it may be radical in its goals, but it does not shut out any 
other nationalist claims wholly. This also likely factored into why Quebecois nationalism could re-examine itself and change its tune in the face of this new narrative eventually, as it did not entirely squander their nationalist goals.

\section{Historical Case Studies}

From this point, I shall begin tracing the shifts in Quebecois attitudes towards Indigenous peoples from antagonistic to cooperative through the usage of historical case studies. The first such case study I shall be examining is the 1975 James Bay Agreement. In early r97I, the Quebec government announced a plan to develop a hydroelectric "Project of the Century" in the Eastern James Bay area of Quebec, an area that traditionally had been and continues to be the home of Cree and Inuit tribes. The project had been planned without consultation or an invitation to share the economic benefits from the land; in turn, the project was challenged by these peoples in the Quebec Superior Court in I972, focusing on "the rights surrounding the ownership and utilization of natural resources and unfulfilled Native land claims in eastern James Bay" (Kirkey 20I5, 88). Although the court ruled in favor of the Cree and Inuit, stating that the Province of Quebec could not develop eastern James Bay land without prior consultation, the James Bay Development Corporation filed two appeals that overruled this decision. (Kirkey 20I5, 88-89) This allowed for the Quebec government to begin negotiating the James Bay Agreement, a land claims agreement that sanctioned the hydroelectric development project and provided Cree and Inuit with "dedicated and protected hunting practices... extension of new social services, and greater political autonomy” (Kirkey 20I5, 90) as a sort of compensation; however, failure on the Quebec and federal governments to quickly implement the agreement led to an "inconsistent disbursement of funds" (Kirkey 2OI5, 9I) for the proposed social services. The blatant disregard of Indigenous consultation, as well as a poor follow-through with promises made to Indigenous peoples, demonstrated the Quebecois figuration of Indigenous peoples as dismissible; in the pursuit of economic benefits to fund the growing Quebecois nationalist project, the interests of the Cree and Inuit in the James Bay area were considered irrelevant.

After the James Bay Agreement, the next important conflictual event between Quebecois and Indigenous nationalism was the Meech Lake Accord. Before the proposal of the Accord in 1987 , the Canadian federal government held various constitutional conferences after the implementation of the new Canadian Constitution in I982. Several of these conferences, taking place in I984, I985 and I987, were focused upon defining Indigenous goals regarding future constitutional amendments (Peach 2OII, 4). This allowed Indigenous people, through four national organizations, to come together to define their objectives in front of the Canadian government and public in an eloquent and articulate manner. This manner of articulation, challenging previously held stereotypes about Indigenous peoples, began to shift the Canadian public's attitude towards Indigenous issues towards a direction of urgency and concern, as evidenced by various polls and media coverage from before and after the negotiations of the Accord (Peach 2OII, 5). The Canadian government's attitudes began to shift as well, paving the road for future land claims settlements. Although these conferences granted Indigenous peoples valuable political capital, they were denied inclusion to the negotiations of the Meech Lake Accord itself, resulting in bitter resentment from the Indigenous community (Peach 2OII, 5-6). The resentment felt was not simply due to being shut out of the negotiations: it was also derived from the Accord "[having] the effect of making [Aboriginal groups] invisible for constitutional purposes" (Peach 2OII, 6), as well as the Canadian government reaching agreements on constitutional amendments and concerns with Quebec behind closed doors, such as the "distinct society 
clause" that would recognize Quebec as a distinct nation within Canada (Peach 2OII, 5-6). Growing distaste for the Accord, influenced by outspoken politicians such as Elijah Harper, Frank McKenna, and Clyde Wells, resulted in the Accord not being implemented (Peach 2OOI, 9-II). Such a defeat for Quebec likely stirred anger and resentment against Indigenous peoples in the citizenry of Quebec, as growing Indigenous concerns and pushes for a three-nation narrative was beginning to undermine Quebecois attempts at pursuing nationalist goals. These sentiments carried themselves over into another prominent and important conflict between Quebecois and Indigenous nationalism: Oka.

The Oka crisis was sparked by local Mohawk resistance to municipals plans to build a golf course on Mohawk territory. The Mohawk established a barricade at Oka in 1990 , which was subsequently attacked by the Sûreté du Québec at the request of the Oka municipal government. The attack left one officer dead, but the barrier remained (Peach 2OII, II-I2). The Quebec government escalated the situation by replacing the Sûreté du Québec with the RCMP, and subsequently the RCMP with the Canadian Army. Tear gas was a common sight at the barricade, as was razor wire and military vehicles (Peach 2OII, I2). The resentment of Quebecers began to rear its ugly head during this time as non-Aboriginal crowds began to harass doctors and patients at the Mercier Bridge, even going so far as to throw stones at a crowd of sick and elderly (Peach 2OII, I2). Alongside physical violence, mainstream press in Quebec attempted to portray Indigenous peoples "as outlaws who posed a danger to law and order" (Peach 2OII, I3) in order to delegitimize the protests and put Oka, and on a larger scale Quebec, in the right. Such events very clearly demonstrated the Quebec figuration of Indigenous peoples as obstacles to development, and did not serve Quebec's cause for a binational narrative that excluded Indigenous peoples; in fact, many Canadians elsewhere were embarrassed by the conduct of Quebec and questioned Quebec's "commitment... to equality and inclusiveness" (Peach 2OII, I3). It was becoming clear that norms were beginning to change; Indigenous nationalist claims were beginning to take hold in Canadian political culture, and there was nothing Quebec could do about it.

Following Oka, the proposed $199^{2}$ Charlottetown Accord attempted to return to issues that had been buried by the defeat of the Meech Lake Accord. Alongside proposed recognition of Quebec as a distinct society, the federal government also proposed a policy that would guarantee a minimum $25 \%$ of House of Common seats for Quebec as a sort of make-up for proposed Senate reforms that would lessen Quebec's power in the upper chamber (Johnston I993, 43-44). As for Aboriginal concessions, the federal government, abiding by suggestions made by the same Indigenous groups who were excluded from the Meech Lake process, proposed to recognize an Indigenous inherent right to self-government, classifying them as a third order of government separate from but equal to the provincial and federal governments (Peach 2OII, I9-2O). Such gains clearly demonstrated a continued shift towards recognition of Indigenous peoples as a "third nation" within Canada, not just as a formality but as a serious issue that the Canadian public care about. A survey conducted by an Indigenous group after the defeat of the Accord reported that some $60 \%$ of Canadians supported the proposed constitutional changes present within the Accord (Peach 2OII, 2O). These gains were squandered by the Accord's defeat, spurred by a Quebec that was reluctant to participate in the negotiations and refused to identify an "irreducible minimum" (Johnston I993, 45) that would spur Quebec to come on-board. The rest of Canada, leaning towards a "Yes" vote, saw an inevitable "No" vote coming from Quebec due to this reluctance, and this crippled support for the "Yes" side (Johnston I993, 47). With the defeat of the Accord, Quebec once again demonstrated a refusal to compromise with Indigenous peoples on constitutional gains, still selfishly clinging onto an idea of a 
decolonizing Quebec whose national goals had to come before the goals of Indigenous groups. The defeat of the Accord, however, also coincided with the defeat of the Quebec sovereignty referendum. The results of the referendum signalled to the Quebec nationalist movement that their narrative and goals were not being received positively by the rest of Canada, likely due to the rising importance of Indigenous issues. Such issues complicated the position Quebec was in; they were, to an extent, a decolonizing nation, but they were still a settler colonial entity that was enacting imperialist policies on Indigenous peoples in order to fulfill their goals. This pressure caused Quebec nationalists to reconsider their positions in the Canadian political landscape and the newly dominating narrative of that landscape: the "three-founding-nations" conception of Canada.

Such reconsiderations became evident in Quebec's formulation a land claim agreement that was based upon a nation-to-nation conception between the Quebecois and Indigenous peoples. Known as the La Paix des Braves agreement, it promised to "make possible an active and ongoing participation by the Crees in economic development activities on the James Bay territory" (Desbiens 2004, 352) in order to rectify issues that arose from the James Bay Agreement, namely those of failed sharing of economic benefits and unfulfilled social program promises. This move formally recognized the historical connection and ownership of the land in the James Bay area by Cree peoples, demonstrating an effort by Quebec to forgo previous attempts to disregard Indigenous claims. This agreement allowed both groups to benefit from economic nationalism in a context that is not simply about competing nationalisms within a local sphere, but instead "within [a] larger context of Canada's own claims to a national territory" (Desbiens 2004, 359). Quebec, through this agreement, finally recognized and accepted the narrative Indigenous peoples had put forward to the rest of Canada as true, shifting their tune from dismissive and antagonistic to one of greater recognition of the settler colonial aspects of Quebecois history and identity, and the requirement to recognize the nationalist claims of Indigenous peoples. Although it was not perfect, as it approached selfgovernment through delegation of economic controls, it was a monumental step away from competition towards cooperation.

\section{Conclusion}

After examination of historical case studies, it is clear to see that Indigenous nationalist claims gradually began to take hold in Canada, popularizing the three-nation conception of Canada in the Canadian political landscape. Quebecois, seeing these Indigenous claims as a threat to the dualist narrative that they supported, initially dismissed and even aggressively attacked the claims out of a fear of sacrificing their nationalist ideals. Eventually, with further popularization of the three-nation narrative, Quebec did change its tune to fall more in accord with the new narrative, shifting its nationalist ideals in order to recognize Indigenous claims as equal. Quebec's unique hybrid position as a decolonizing nation and a settler-colonial nation allowed for this change by embedding Quebecois nationalism with a degree of empathy for other disenfranchised groups in the Canadian political context. While the recognition shown at La Paix des Braves was mostly symbolic and did not grant true self-government to the Cree and Inuit in the James Bay Area, it is a far-cry from the dismissal and aggression shown during the lead-up to the James Bay Agreement as well as Oka. Only time will tell if Quebec begins to further accommodate First Nations claims to self-government; as with the rest of Canada, they are making slow progress. 


\section{Bibliography}

Austin, David. "Narratives of Power: Historical Mythologies in Contemporary Québec and Canada.” Race and Class 5 , no. I (20IO): I9-32. doi:IO.II77/o3063968IO37I759

Desbiens, Caroline. "Nation to Nation: Defining New Structures of Development in Northern Quebec." Economic Geography 80, no. 4 (2004): 35 I-66. doi:IO.IIII/j.I9448287.2004.tboo242.X

Hobbs, Sandra. "Figures of the Native in $20^{\text {th }}$-Century Quebec: The Subaltern and the Colonial Subject at the Intersection of Colony and Nation." Journal of Postcolonial Writing 44,no. 3 (2008): 307-I8. doi:Io.Io80/I7449850802230640

Jenson, Jane. "Naming Nations: Making Nationalist Claims in Canadian Public Discourse." C Canadian Review of Sociology and Anthropology 30, no. 3 (1993): 337-58.

Johnston, Richard. “An Inverted Logroll: The Charlottetown Accord and the Referendum.” PS: Political Science and Politics 26, no. I (I993): 43-8.

Kirkey, Mackenzie. “The James Bay Northern Quebec Agreement.” Journal of Eastern Township Studies 45 (20I5): 85-96.

McRoberts, Kenneth. "Canada and the Multinational State." Canadian Journal of Political Science 34, no. 4 (200I): 683-7I3. doi:Io.IOI7/Sooo842390I778055

Peach, Ian. "The Power of a Single Feather: Meech Lake, Indigenous Resistance and the Evolution of Indigenous Politics in Canada." Review of Constitutional Studies I6, no. I (20II): I-29. 